\title{
Kariyer Psikolojik Danışmanlığına Yönelik Tutumda Kendini Damgalamanın Aracı Rolüa
}

\author{
Aida Köse ${ }^{b}$, Furkan Kirazc1 ${ }^{c, d}$, Yaşar Barute, Ayşenur Büyükgöze-Kavas ${ }^{\mathrm{f}}$
}

\section{Özet}

Üniversite dönemi kişilerin kariyerlerinde önemli bir yere sahiptir. Bu dönemde kariyerleri ile ilgili çeşitli kararlar vermek durumunda olan öğrencilerin profesyonel bir yardıma ihtiyaç duymaları kaçınılmazdır. Fakat ilgili araştırmalar çok az sayıda üniversite öğrencisinin kariyer psikolojik danışmanlığı hizmetlerinden yararlandığını ortaya koymaktadır. Mevcut araştırmada ise üniversite öğrencilerinin kariyer psikolojik danışmanlığına yönelik tutumlarının kendini damgalamanın aracı rolüyle sosyal damgalanma ve yakın çevre damgalanması tarafından ne düzeyde yordandığı incelenmektedir. Araştırmada ayrıca öğrencilerin kariyer psikolojik danışmanlığına yönelik tutumlarının cinsiyete göre değişip değişmediği de test edilmiştir. İlişkisel araştırma deseni temelinde yürütülen araştırmada 500 üniversite öğrencisinden veri toplanmıştır. Toplanan veriler üzerinde yapılan yol analizi sonucunda bağımsız değişkenlerin kariyer psikolojik danışmanlığına yönelik tutumu anlamlı şekilde yordadığı ve bu ilişkide kendini damgalamanın anlamlı bir aracılık rolü olduğu görülmüştür. Ayrıca kariyer psikolojik danışmanlığına yönelik tutumun cinsiyete göre farklılaşıp farklılaşmadığı $t$ testine göre incelenmiş ve kadınların erkeklere göre kariyer psikolojik danışmanlığına yönelik daha olumlu tutuma sahip oldukları sonucuna ulaşılmıştır. Elde edilen bulgular ilgili alanyazına dayalı olarak tartışılmıştır.

\section{The Mediator Role of Self-Stigma in Attitudes Towards Career Counseling}

\begin{abstract}
University period has an important place in people's careers. During this period, it is inevitable that students who have to make various decisions about their careers need professional help. However, relevant studies reveal that very few university students benefit from career counseling services. In the current study, it is examined to what extent university students' attitudes towards career counseling are predicted by the mediating role of self-stigma, public stigma, and stigma of close other. In the study, it was also tested whether students' attitudes towards career counseling changed according to gender. Data were collected from 500 university students in the research conducted on the basis of the relational research design. As a result of the path analysis on the collected data, it was seen that the independent variables significantly predicted the attitude towards career counseling and self-stigma played a significant mediating role in this relationship. In addition, it was examined whether the attitude towards career counseling differs according to gender, according to the $t$-test, and it was concluded that women had more positive attitudes towards career counseling than men. The findings were discussed based on the relevant literature.
\end{abstract}

Anahtar Kelimeler

Kariyer Psikolojik Danışmanlığ 1

Kendini Damgalama

Sosyal Damgalama

Yakın Çevre Damgalaması

Makale Hakkında

Geliş Tarihi: 27.09.2021

Kabul Tarihi: 15.12.2021

Doi: 10.18026/cbayarsos.1000821

Career Counseling
Self-Stigma
Public Stigma
Stigma of Close Other

About Article

Received: 27.09.2021

Accepted: 15.12.2021

Doi: 10.18026/cbayarsos.1000821

\footnotetext{
a Bu çalışma ilk yazarın yayınlanmamış yüksek lisans tezinden üretilmiştir.

b Uzm., Ondokuz Mayıs Üniversitesi Kurupelit Kampüsü Eğitim Fakültesi A Blok Atakum/SAMSUN, 0000-0001-7773-2611.

cİletişim yazarı: furkan.kirazci@omu.edu.tr

d Arş. Gör., Ondokuz Mayıs Üniversitesi Kurupelit Kampüsü Eğitim Fakültesi A Blok Atakum/SAMSUN, 0000-0002-8829-3615.

e Doç. Dr., Ondokuz Mayıs Üniversitesi Kurupelit Kampüsü Eğitim Fakültesi A Blok Atakum/SAMSUN, 0000-0003-1602-2477.

f Prof. Dr., Ondokuz Mayıs Üniversitesi Kurupelit Kampüsü Eğitim Fakültesi A Blok Atakum/SAMSUN, 0000-0001-9072-7040.
} 


\section{Giriş}

Üniversite hayatı, ergenlik döneminden beliren yetişkinliğe adım atan bireylerin farklı yeni yaşantıları tecrübe ettikleri bir dönem olarak değerlendirilebilir. Bu öğrenim süresi zarfında öğrenciler sosyal ve bireysel çeşitli problemlerle başa çıkarken bir yandan da akademik ve mesleki konularda karar vermek ve karşılaştıkları zorlukların üstesinden gelmek zorunda kalmaktadırlar. Dolayısıyla öğrenciler kariyerleri ile ilgili konularda sıklıkla ve artan bir biçimde profesyonel bir yardıma ihtiyaç duyabilmektedirler. Bu konu hakkında araştırmacılar üniversite öğrencilerinin, kariyer gelişimi alanında diğer alanlara kıyasla daha fazla yardıma ihtiyaç duyduklarının altını çizmektedirler (Korkut-Owen, 2018; Yerin-Güneri ve ÇapaAydın, 2010). Bu durum üniversite öğrencilerine yönelik kariyer psikolojik danışmanlığ hizmetlerinin önemini vurgulamaktadır.

Kariyer psikolojik danışmanlığının etkileri üzerine yapılan çalışmalar kariyer psikolojik danışmanlığı kapsamındaki müdahalelerin öğrencilerin kaygı ve stres düzeylerini ciddi şekilde azalttığını ve kariyer gelişimlerinde oldukça etkili olduğunu göstermiştir (Multon, Heppner, Gysbers, Zook ve Ellis-Kalton, 2001; Whiston ve Rahardja, 2008). Kariyer psikolojik danışmanlığı müdahalelerinin pozitif etkilerine rağmen araştırmalar üniversite öğrencilerinin birçoğunun kariyerleri ile ilgili sıkıntı yaşamalarına rağmen çok azının kariyer danışmanlığ hizmetlerinden yararlandığını göstermektedir (Fouad, Guillen, Harris-Hodge, Henry, Novakovic, Terry ve Kantamneni, 2006). Yurtdışında yapılan bir araştırmada üniversite öğrencilerinin \%17 ile \%22'si doğrudan mesleki sorunları olduğunu belirtmiş, farklı bir araştırmada ise üniversite öğrencilerinin yalnızca \%6.3'ü kariyer danışmanlığı hizmetlerinden yararlandıklarını ifade etmişlerdir (Fouad vd., 2006). Türkiye'de ise Işık (2007) tarafından yapılan bir araştırma sonucunda öğrencilerin yalnızca \%5.4'ünün kariyer danışmanlığ hizmetlerinden yararlandığ 1 sonucuna ulaşılmıştır.

Alanyazında kariyer gelişimi ile ilgili sorunlar yaşayan kişilerin çoğunluğunu profesyonel yardım aramaktan alıkoyan şeyin ne olduğunu inceleyen çeşitli araştırmalara rastlanmaktadır. Örneğin bu konu ile ilgili Ludwikowski, Vogel ve Armstrong (2009) araştırmalarında üniversite öğrencilerinin kariyer psikolojik danışmanlığına yönelik tutumlarının çeşitli şekillerde damgalanma yaşayacaklarına yönelik düşünceleri tarafından yordandığı sonucuna ulaşmışlardır. Benzer şekilde Rochlen, Mohr ve Hargrove (1999)'da kariyer psikolojik danışmanlığına yönelik tutum ölçeğini geliştirdikleri çalışmalarında ölçeğin damgalanma alt boyutu ile kariyer psikolojik danışmanlığı hizmetinden yararlanma düzeyi arasında negatif yönlü bir ilişki bulmuşlardır. Al-Darmaki (2012) tarafından yapılan bir çalışmada üniversite öğrencilerinin kariyer psikolojik danışmanlığına yönelik tutumları ile öz-yetkinlik ve öz-saygı arasındaki ilişki incelenmiştir. Buna göre öz-saygı ve öz-yetkinlik ile kariyer danışmanlığına yönelik damgalanma arasında negatif yönlü ilişkinin olduğu görülmüştür. Lau, Anctil, Ee, Jaafar ve Kin (2020) ise yaptıkları araştırmada olumlu benlik kavramı ile kariyer psikolojik danışmanlığına yönelik değer algısı arasında pozitif yönlü ilişki bulmuşlardır. Genel olarak konu ile ilgili araştırmalar göz önünde bulundurulduğunda öğrencilerin kariyer psikolojik danışmanlığına yönelik tutumlarında damgalanma, öz-saygı, öz-yetkinlik ve benlik kavramlarının rolünün olduğu görülmektedir. Diğer taraftan yurtiçinde yapılan araştırmalar incelendiğinde ise öğrencilerin kariyer psikolojik danışmanlı̆̆ına yönelik tutumlarını ele alan herhangi bir çalışmanın olmadığı görülmüştür. Buna karşın alanyazında Türkiye'deki üniversite öğrencilerinin psikolojik yardım almaya ilişkin tutumlarına etki eden faktörlerin ele alındığı çeşitli araştırmalar mevcuttur. Örneğin Kızıldağ, Demirtaş-Zorbaz, Gençtanırım ve 
Arıcı (2012) tarafından yapılan çalışmada üniversite öğrencilerinin \%52'si psikolojik danışma yardımı almaya yönelik çevresel bir engellerinin bulunmadığını belirtirken sadece \%14'ü bu hizmetten yararlandıklarını ifade etmişlerdir. Diğer taraftan öğrencilerin psikolojik yardım almaktan çekindikleri konuların başında başkaları tarafından alay edilme ya da etiketlenme korkusu gelmektedir (Kızıldağ ve ark., 2012). Gürsoy ve Gizir (2018) tarafından yapılan bir çalışmada ise öğrencilerin psikolojik yardım almaya ilişkin tutumlarının sosyal damgalanma, kendini damgalama ve cinsiyet açısından değişiklik gösterdiği sonucuna ulaşılmıştır. Buna göre psikolojik yardım alma nedeniyle sosyal damgalanma yaşayacaklarını düşünen ve kendini damgalama eğiliminde olan kişilerin psikolojik danışmaya karşı daha olumsuz bir tutum içinde oldukları görülmüştür. Bu araştırmalara benzer olarak Sezer ve Güllüoğlu (2016) ise kişilerin psikolojik yardım almaya yönelik tutumlarının sahip oldukları öz-saygı, kendini damgalama ve daha önce psikolojik bir yardım almış olup olmama değişkenleri tarafından ne düzeyde yordandığını incelemişlerdir. Buna göre öz-saygısı yüksek olan kişilerin psikolojik danışma yardımı almaya ilişkin daha olumlu bir tutum içinde oldukları sonucuna ulaşılmıştır. Diğer taraftan daha önce psikolojik yardım almış olan kişilerin ise psikolojik danışmaya karşı olumlu tutum sergiledikleri görülmüştür. Diğer araştırmalara benzer olarak kendini damgalama ile psikolojik danışmaya karşı olumlu tutum sergileme arasında ise negatif yönlü bir ilişki bulunmuştur (Sezer ve Güllüoğlu, 2016). Serim ve Cihangir-Çankaya (2015) ise psikolojik yardım arama değişkeninin yordayıcılarını inceledikleri araştırmalarında kendini saklama ve duyguları ifade etme değişkenlerinin psikolojik yardım aramaya yönelik tutum üzerindeki rollerini incelemişlerdir. Buna göre kendini saklama ile psikolojik yardım aramaya yönelik tutum arasında negatif yönlü bir ilişki bulunurken, duyguları ifade etme ile yardım aramaya karşı tutum arasında pozitif yönlü bir ilişki bulunmuştur (Serim ve CihangirÇankaya, 2015). Çivan (2019) tarafından yapılan yüksek lisans tez çalışması kapsamında ise rehberlik ve psikolojik danışmanlık öğrencilerinin psikolojik yardım almaya yönelik tutumlarının çeşitli değişkenlere göre farklılaşıp farklılaşmadığı incelenmiştir. Buna göre yukarıdaki çalışmalara benzer olarak kadın öğrencilerin ve daha önce psikolojik yardım almış olan kişilerin psikolojik yardım almaya yönelik daha fazla olumlu tutum sergiledikleri sonucuna ulaşılmıştır.

Yukarıdaki araştırmalardan hareketle yurtiçinde üniversite öğrencilerinin psikolojik danışmaya karşı tutumlarını değerlendiren çok sayıda çalışmanın olduğu söylenebilir. Buna karşın, ilgili alanyazında öğrencilerin kariyer psikolojik danışmanlığına yönelik tutumlarını değerlendiren herhangi bir çalışmaya rastlanmamıştır. Bu bağlamda, mevcut çalışmanın amacı kişilerin kariyer psikolojik danışmanlığına yönelik tutumlarında sosyal damgalama, yakın çevre damgalaması ve kendini damgalama faktörlerinin ne düzeyde rol oynadığını ara değişkenli bir model kapsamında araştırmaktır. Bu amaçla sosyal damgalanma, yakın çevre damgalanması ve kendini damgalamanın ne olduğu ve kariyer psikolojik danışmanlığına yönelik tutumda ne gibi bir rol oynayabileceği kısaca açıklanmaya çalışılacaktır. Ayrıca, bu araştırmanın diğer bir amacı ise kariyer psikolojik danışmanlığına yönelik tutumların cinsiyete göre farklılaşıp farklılaşmadığını incelemektir.

\section{Damgalanma ve Kariyer Psikolojik Danışmanlı̆̆ı}

Damgalanma bir kişinin diğer kişiler tarafından hoş karşılanmamasına yol açan bir özelliğe sahip olmasından dolayı diğerlerinden soyutlanmasıyla sonuçlanan bir durum olarak nitelendirilmektedir (Kim, Britt, Klocko, Riviere ve Adler, 2011). Damgalanma nedeniyle 
yaşanan korku ise kişinin yaşam doyumunu olumsuz yönde etkileyen karmaşık psikolojik ve sosyal bir durumdur. Psikolojik bir yardım hizmeti alma nedeniyle damgalanma, bireyin psikolojik bir yardım alması durumunda kendi değerinin azalması, diğer kişiler tarafından reddedilme ve dışlanabileceğine ilişkin algıyı yansıtmaktadır (Major ve O'Brien, 2005). Psikolojik yardım alma nedeniyle damgalanma durumları damgalayan taraf bakımından çeşitli farklılıklar gösterebilir. Buna göre psikolojik bir yardım hizmeti alma nedeniyle sosyal damgalanma, kişinin psikolojik yardım alması durumunda çevrenin kendisini damgalayacağına yönelik sahip olduğu algıyı ifade ederken, psikolojik yardım alma nedeniyle kendini damgalama ise kişinin kendini damgalamasını ifade etmektedir (Vogel, Wade ve Hackler, 2007). Sosyal damgalanma ve kendini damgalama dışında, kişinin etkileşimde bulunduğu kişilerin tepkileri yoluyla da bir damgalanma olabilmektedir ve bu durum alanyazında yakın çevre damgalanması olarak ifade edilmektedir (Vogel, Wade ve Ascheman, 2008). Buna göre eğer kişinin arkadaşları ya da ailesi psikolojik yardım almaya karşı olumlu bir görüşe sahipse kişinin psikolojik danışma yardımı alma olasılığı daha yüksek olabilmektedir (Vogel, Wade, Wester, Larson ve Hackler, 2007). Bunun tam tersi de mümkündür ve bu durumda kişiler ailelerinden psikolojik danışma alma nedeniyle olumsuz tepki alacağını düşünürse, psikolojik yardım hizmetlerinden yararlanma olasılıkları da diğerlerine göre daha düşük olacaktır (Leaf, Bruce ve Tischler, 1986).

Alanyazında damgalanma ile psikolojik yardım alma ve kariyer psikolojik danışmanlığına yönelik tutum arasındaki ilişkileri inceleyen bazı araştırmalar bulunmaktadır (Gürsoy ve Gizir, 2018; Ludwikowski vd., 2009; Sezer ve Gülleroğlu, 2016; Vogel, Wade ve Haake, 2006).Bu araştırmalar detaylı bir şekilde incelendiğinde damgalanmanın çeşitli boyutlarıyla (kişisel, yakın çevre ya da sosyal damgalama gibi) kariyer psikolojik danışmanlığına yönelik tutum arasındaki ilişkiyi inceleyen oldukça sınırlı sayıda çalışmanın olduğu görülmektedir. Ludwikowski ve arkadaşları (2009) tarafından yapılan araştırmada farklı damgalanma türleri ile kariyer psikolojik danışmanlığına yönelik olumlu tutum arasındaki ilişkiler yol analizi ile incelenmiştir. Ludwikowski ve arkadaşlarının (2009) araştırmasına benzer olarak mevcut araştırmada da kariyer psikolojik danışmanlığına yönelik tutumun alt boyutları olan değer ve damgalanma değişkenlerinin sosyal damgalanma, yakın çevre damgalanması ve kendini damgalama tarafından ne düzeyde yordandığ 1 Şekil 1'de görülen modele göre incelenecektir.

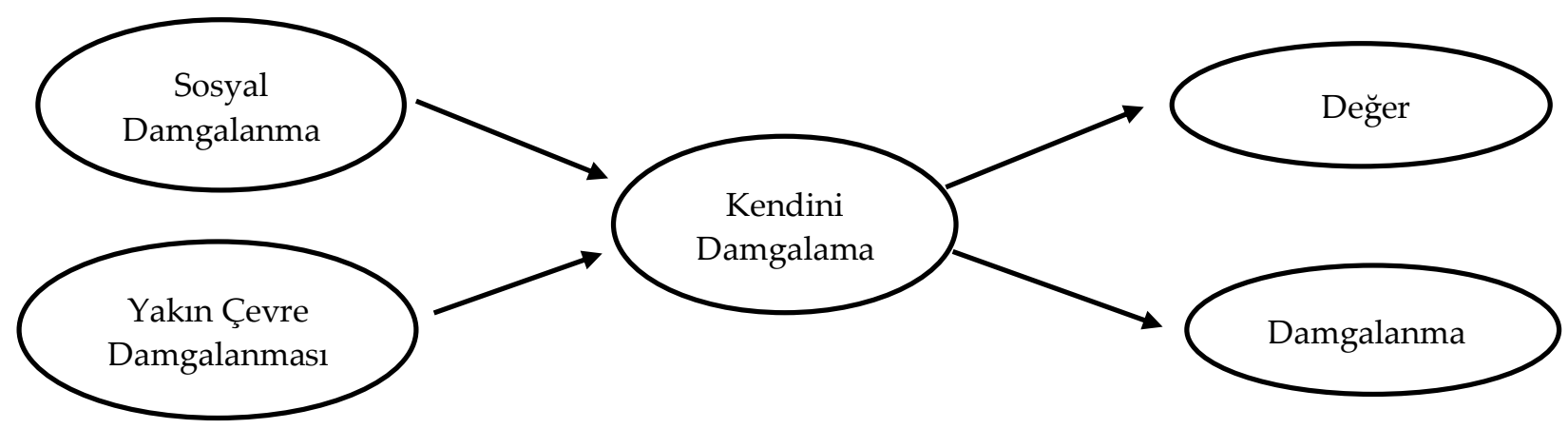

Şekil 1. Damgalanmanın kariyer danışmanlığına yönelik tutumdaki rolü

Şekil 1'deki modele göre sosyal damgalanma ve yakın çevre tarafından damgalanmanın, kariyer psikolojik danışmanlığına yönelik tutum ölçeğinin damgalanma alt boyutunu 
doğrudan yordadığı varsayılmaktadır. Bu varsayımın temelinde kişinin çevresi tarafından damgalanacağına yönelik algısının onun kariyer psikolojik danısma alması dolayısıyla damgalanacağını öngördügünü yordaması yatmaktadır. Özellikle bir kariyer seçiminde ailenin, çocuklarının geleceği hakkında bazı beklentileri olabilir. Fakat kişinin bu beklentileri göz ardı ederek bir kariyer danışması yardımı alması çevreden gelecek olan olumsuz tepkilere yol açabilir. Buna göre kişinin yakın çevresi tarafından damgalanacağına yönelik algısı onun kariyer psikolojik danışmanlığına yönelik tutumunu olumsuz etkileyebilir. Diğer taraftan kendini damgalamanın sosyal damgalanma ve yakın çevre damgalanması ile kariyer psikolojik danışmanlığına yönelik tutumunun iki alt boyutu arasında aracılık rolünün olduğu varsayılmıştır. Kendini damgalama, bireyin yardım aradığı için kişisel olarak kabul edilemez olduğu algısıdır (Vogel vd., 2006). Fakat Vogel ve arkadaşları (2007), kendini damgalamanın çevresel damgalama ile profesyonel yardım aramaya yönelik tutumlar arasındaki ilişkiye tam olarak aracılık ettiği bulgusuna ulaşmışlardır. Benzer bir bulgu da Ludwikowski ve arkadaşlarının (2009), kariyer psikolojik danışmanlığı ile ilgili çalışmasında ortaya çıkmıştır. Bu sonuçlar dış damgalamaların kendini damgalama olarak içselleştirilebileceği ve daha sonra kendini damgalamanın yardım arama konusundaki tutumları şekillendirmede doğrudan bir rol oynayabileceğini göstermektedir. Dolayısıyla mevcut çalışmada da kendini damgalama aracı bir değişken olarak konumlandırılmıştır.

\section{Kariyer Psikolojik Danışmanlı̆̆ına Yönelik Tutumda Cinsiyetin Rolü}

Mevcut araştırmada kariyer psikolojik danışmanlığına yönelik tutumun cinsiyete göre farklılaştığı varsayılmaktadır. Konu ile ilgili çalışmalar yapan araştırmacılar erkeklerin hem psikolojik danışma almada hem de kariyer danışması almada kadınlara göre daha fazla damgalanacaklarına yönelik algıya sahip olduklarını belirtmektedirler (Ludkowski vd., 2009; Rochlen vd., 1999; Vogel vd., 2008). Bunun tersine farklı çalışmalar ise kadınların psikolojik danışma yardımına karşı erkeklere göre daha olumlu bir tutum içinde olduklarını göstermiştir (Serim ve Cihangir-Çankaya, 2015; Sezer ve Güllüoğlu, 2016). Bunlara ek olarak konu ile ilgili çeşitli araştırmalarda da cinsiyetin psikolojik yardım almaya yönelik tutumda önemli bir rolünün olduğu vurgulanmaktadır (Gürsoy ve Gizir, 2018; Kalkan ve Odac1, 2005; Zeren, Erus ve Amanvermez, 2017). Genel olarak araştırmacılar erkeklerin psikolojik yardım alma durumunu daha çok yetersizlik olarak gördüklerini ifade etmektedirler (Vogel vd., 2007). Diğer taraftan kadınlar ve erkekler arasındaki psikolojik yardım alma ya da kariyer psikolojik danışmanlığından yararlanmaya yönelik tutumları toplumsal cinsiyet rolleriyle açıklanmaktadır. Ludwikowski ve arkadaşları (2009) özellikle kariyer karar verme konusunda erkeklerin geleneksel cinsiyet rollerinden kaynaklı olarak daha kararlı olmaları gerektiğine yönelik düşüncelerinin yardım arama davranışında etkili olduğunu belirtmektedir. Söz konusu araştırmalar genel olarak değerlendirildiğinde ise cinsiyetin psikolojik yardım aramaya yönelik tutumda önemli bir etken olduğu görülmektedir.

\section{Yöntem}

Üniversite öğrencilerinin kariyer psikolojik danışmanlığına yönelik tutumlarında sosyal damgalanma, yakın çevre damgalanması ve kendini damgalamanın rolünün incelenmesinin amaçlandığ 1 bu araştırmada ilişkisel araştırma deseni kullanılmıştır. 


\section{Araştırma Grubu}

Araştırmanın örneklemini üniversitede çeşitli fakültelerde lisans düzeyinde öğrenim gören 371 kadın (\%74.2), 129 erkek (\%25.8) olmak üzere toplamda 500 üniversite öğrencisi oluşturmaktadır. Araştırmaya katılan öğrencilerin yaşları 18 ile 29 (Ort. 21.11; Ss. 1.90) arasında değişmektedir. Araştırmaya katılan öğrencilerin 205'i eğitim fakültesi (\%41), 81'i iktisadi ve idari bilimler fakültesi (\%16.2), 156's1 fen-edebiyat fakültesi (\%31.2), 35'i sağlık bilimleri fakültesi (\%7) ve 23'ü spor bilimleri fakültesinde (\%4.6) öğrenim görmektedir. Katılımcıların sınıf düzeyine göre dağılımlarına bakıldığında ise 104 kişinin 1. sınıf (\%20.8), 105 kişinin 2. sınıf (\%21), 130 kişinin 3. sınıf (\%26) ve 161 kişinin 4. sinıfta (\%32.2) öğrenim gördüğü söylenebilir.

\section{Veri Toplama Araçları}

Verilerin ölçek doldurma yoluyla elde edildiği araştırmada katılımcılardan kendilerine verilen formları doldurmaları istenmiştir. Veri toplama işlemi sırasında araştırmacının kendisi öğrencilere gerekli açıklamaları yapmış ve gönüllü olan katılımcılara ölçek formlarını dağıtmıştır. Araştırmada katılımcılara Kariyer Psikolojik Danışmanlığına Yönelik Tutum Ölçeği, Psikolojik Yardım Aramada Kendini Damgalama Ölçeği (PYAKDÖ), Psikolojik Yardım Alma Nedeniyle Sosyal Damgalanma Ölçeği (PYANSDÖ) ve Psikolojik Yardım Aramada Yakın Çevre Damgalaması Ölçeği (PYAYÇDÖ) uygulanmıştır. Ayrıca katılımcılara yaş, cinsiyet ve sınıf düzeyi sorularının yer aldığı kişisel bilgi formları verilmiştir. Katılımcılardan veri toplamadan önce üniversitenin ilgili kurulundan etik kurul izni alınmıştır.

Kariyer Psikolojik Danışmanlığına Yönelik Tutum Ölçeği (KPDYTÖ). Rochlen, Mohr ve Hargrove (1999) tarafından geliştirilmiştir. Ölçek, kariyer psikolojik danışmanlığına verilen değer (value) ve kariyer psikolojik danışmanlığına yönelik damgalanma (stigma) isimli iki alt ölçekten ve toplam 16 madden oluşmaktadır. Her iki alt ölçekte de dörtlü derecelendirme sistemine göre (1: Katılmiyorum 2: Kismen katılmiyorum 3: Kismen katıliyorum 4: Katılıyorum) puanlanan 8 madde yer almaktadır. Ölçeğin alt boyutlarından alınan puanlar arttıkça kariyer danışmanlığına yönelik olumlu tutum ve damgalanma korkusu artmaktadır.

KPDYTÖ'nün Türkçe’ye uyarlama çalışması Büyükgöze-Kavas (2017) tarafından yapılmıştır. Uyarlama çalışması kapsamında ölçeğin orijinal faktör yapısının sınanması amacıyla iki farklı veri setiyle doğrulayıcı faktör analizi yapılmış ve elde edilen bulguların orijinal çalışma bulgularını destekler nitelikte olduğu belirtilmiştir. Bununla birlikte hesaplanan iç tutarlılık katsayıları ise "değer" alt boyutu için .92, damgalanma alt boyutu için ise .89 olarak hesaplanmıştır. Ayrıca bir gruba altı hafta ara ile test-tekrar test uygulaması yapılmış ve iki uygulama arasında değer alt boyutu için .71, damgalanma alt boyutu için ise .76 düzeyinde anlamlı bir korelasyon bulunmuştur. Sonuç olarak elde edilen verilerin bir bütün olarak değerlendirildiğinde KPDYTÖ'nün Türkçe Formunun uygulamalarda ve araştırmalarda kullanılabilecek nitelikte geçerli ve güvenilir bir ölçme aracı olduğu sonucuna varılmıştır (Büyükgöze-Kavas, 2017). Mevcut araştırmada ise ölçeğin değer alt boyutunun alfa katsayısı .91 , damgalanma alt boyutunun alfa kat sayısı ise .89 olarak bulunmuştur.

Psikolojik Yardım Aramada Kendini Damgalama Ölçeği (PYAKDÖ). Vogel, Wade ve Haake (2006) tarafından geliştirilen ölçek, kişilerin psikolojik bir yardım hizmeti almalarından dolayı kendilerini ne düzeyde damgaladıklarını ölçmektedir. " $1=$ Kesinlikle katılmıyorum, 5= 
Kesinlikle katılıyorum" şeklinde dereceleme yapısına sahip olan ölçek toplamda 10 maddeden oluşmaktadır. Ölçekten alınan yüksek puanlar, psikolojik bir yardım hizmeti alması durumunda kişinin kendini damgalayacağını; düşük puanlar ise, bir psikolojik yardım alma durumunda kişinin kendini damgalama düzeyinin düşük olacağına işaret etmektedir.

Türkçe'ye uyarlaması Acun-Kapıkıran ve Kapıkıran (2013) tarafından yapılan ölçeğin benzer ölçek geçerliği kapsamında, PYANKDÖ ile Psikolojik Yardım Almaya İlişkin Tutum Ölçeği (PYAİTÖ) arasındaki ilişki incelenmiştir. Bunun sonucunda iki ölçek arasında pozitif yönde ve anlamlı bir ilişki bulunmuştur $(r=.49, p<.01)$. Ölçeğin güvenirlik çalışması kapsamında Cronbach Alfa iç tutarlılık katsayısı hesaplanmış ve .71 olarak rapor edilmiştir. Mevcut araştırmada ise ölçeğin alfa iç tutarlılık katsayısı .82 olarak hesaplanmıştır.

Psikolojik Yardım Alma Nedeniyle Sosyal Damgalanma Ölçeği. Komiya, Good ve Sherrod (2000) tarafından geliştirilen ölçek, kişinin psikolojik bir yardım hizmeti alması durumunda sosyal çevre tarafından ne düzeyde damgalanacağına yönelik düşüncesini ölçmektedir. "1= Kesinlikle katılmıyorum, 4= Kesinlikle katılıyorum" şeklinde dörtlü likert yapıya sahip olan ölçek toplamda 5 maddeden oluşmaktadır. Ölçekten alınan puanların yükselmesi kişinin psikolojik bir yardım hizmeti almasından dolayı çevre tarafından damgalanacağına yönelik beklentisinin arttığına işaret ederken; ölçekten alınan düşük puanlar ise kişinin psikolojik bir yardım alması durumunda toplum tarafından damgalanacağına yönelik daha düşük bir beklentisi olduğuna işaret etmektedir.

Ölçeğin Türkçe'ye uyarlaması Topkaya (2011) tarafından yapılmıştır. Türkçeye uyarlama çalışmasında ölçeğin geçerlilik analizleri kapsamında doğrulayıcı faktör analizi yapılmış ve elde edilen değerlerin yeterli düzeyde olduğu sonucuna ulaşılmıştır. Ayrıca PYANSDÖ'nün güvenirlik çalışması kapsamında ise Cronbach Alfa iç tutarlılık katsayısı hesaplanmış ve .80 olarak rapor edilmiştir (Topkaya, 2011). Şimdiki araştırmada ise ölçeğin alfa iç tutarlılık katsayısı .75 olarak hesaplanmıştır.

Psikolojik Yardım Aramada Yakın Çevre Damgalanması Ölçeği (PYAYÇÖ). Vogel ve arkadaşları (2009) tarafından geliştirilen Psikolojik Yardım Aramada Yakın Çevre Damgalaması Ölçeği kişilerin etkileşim içinde olduğu sosyal grup tarafından damgalanma yaşayacaklarına ilişkin algıyı ölçmektedir. 5 maddeden oluşan ölçek 5'li likert (1= Hiç katılmıyorum, 5= Tamamen katılıyorum) yapıya sahiptir. Ölçekten alınan yüksek puanlar kişinin yardım arama davranışı gösterdiğinde yakın çevresinden damgalanma yaşayacağına yönelik algısının yüksek olduğunu göstermektedir.

Ölçeğin Türkçeye uyarlama çalışması Sezer ve Kezer (2013) tarafından gerçekleştirilmiştir. Ölçeğin geçerlilik çalışması kapsamında açımlayıcı ve doğrulayıcı faktör analizleri yapılmış ve bu analizler sonucunda Türkçe formun orijinal formdaki gibi tek faktörlü iyi uyum gösterdiği sonucuna ulaşılmıştır. Ölçeğin güvenirlik çalışmaları için ise alpha katsayısı hesaplanmış ve test-tekrar test yöntemi uygulanmıştır. Buna göre ölçeğin alpha katsayısı .93, test-tekrar test sonucu ise .80 olarak rapor edilmiştir. Mevcut araştırmada ise ölçeğin alfa iç tutarlılık katsayısı .95 olarak hesaplanmıştır.

Kişisel Bilgi Formu. Araştırmada katılımcıların yaşlarını, cinsiyetlerini, sınıf düzeylerini ve fakültelerini öğrenmeye yönelik kapalı uçlu soruların bulunduğu kişisel bilgi formu kullanılmıştır. 


\section{Verilerin Analizi}

Araştırmanın amaçları doğrultusunda kariyer psikolojik danışmanlığına yönelik tutumun cinsiyete göre anlamlı bir farklılık gösterip göstermediğini test etmek için bağımsız örneklemler $t$ testi yapılmıştır. Sonrasında araştırma kapsamında oluşturulan modelin testi için ise yol (path) analizi kullanılmıştır. Path analizi çoklu regresyon analizine dayanan ve ikiden fazla değişkenin bulunduğu modelleri parametre tahminlerine dayalı olarak test edebilen bir analiz çeşididir (Çokluk, Şekercioğlu ve Büyüköztürk, 2014). Verilerin analizinde SPSS 17 ve AMOS 18 paket programlarından yararlanılmıştır. Analizlere geçilmeden önce varsayımların karşılanıp karşılanmadığını incelemek amacıyla tüm ölçeklerde puanların normal dağılıp dağılmadığı incelenmiş ve bağımsız değişkenler arasında çoklu bağlantının olup olmadığını test etmek için değişkenler arası korelasyon katsayıları hesaplanmıştır. Daha sonra veri setinde uç değerleri tespit etmek için ise verilerin Mahanolobis uzaklıkları hesaplanmış ve buna göre veri setinden uç değer olarak kabul edilen 25 veri silinmiştir. Genel olarak bakıldığında veri setinin söz konusu analizler için varsayımları karşıladığı sonucuna ulaşılmıştır.

\section{Bulgular}

Araştırmanın ilk amacı doğrultusunda katılımcıların cinsiyetlerine göre kariyer psikolojik danışmanlığına yönelik tutumlarının anlamlı bir değişiklik gösterip göstermediklerini incelemek amacıyla bağımsız örneklemler $t$-testi yapılmıştır. Yapılan $t$ testi sonucunda elde edilen bulgular Tablo 1'de verilmektedir.

Tablo 1. Kariyer Psikolojik Danışmanlığına Yönelik Tutumun Cinsiyete Göre Karşılaştırılması

\begin{tabular}{ccccccc}
\hline & Cinsiyet & $\mathrm{N}$ & $\overline{\mathrm{x}}$ & Ss & $t$ & $p$ \\
\hline Kar. Psik. Dan. & Kadın & 371 & 27.57 & 4.68 & 4.768 & .552 \\
Değer & Erkek & 129 & 25.25 & 5.01 & & \\
\hline Kar. Psik. Dan. & Kadın & 371 & 11.91 & 4.70 & \multirow{2}{*}{-6.018} & $.001^{*}$ \\
Damgalanma & Erkek & 129 & 14.94 & 5.57 & & \\
\hline
\end{tabular}

${ }^{*} p<.05$

Tablo 1'de görüldügü üzere kariyer psikolojik danışmanlığına yönelik tutum cinsiyete göre incelendiğinde damgalanma alt boyutunda kadınlar ve erkekler arasında anlamlı bir farklılık bulunmaktadır $(t(500)=-6.018 ; p<.05)$. Puan ortalamalarına bakıldığında ise erkeklerin kariyer psikolojik danışmanlığına yönelik damgalanma algılarının daha yüksek olduğu görülmektedir. Diğer taraftan kariyer psikolojik danışmanlığına yönelik değer alt boyutuna bakıldığında ise cinsiyetler arasında anlamlı bir farklılı̆̆ın olmadığ 1 söylenebilir.

Araştırmanın bir diğer amacı olan model testi için ise yol analizi yapılmıştır. Yol analizinin temel varsayımları için öncelikle değişkenler arası korelasyon değerleri incelenmiştir. Değişkenler arası korelasyon değerleri Tablo 2' de verilmektedir. 
Tablo 2. Değişkenlerin Ortalama, Standart Sapma ve Korelasyon Katsayı Değerleri

\begin{tabular}{cccccccc}
\hline & $\overline{\mathrm{x}}$ & Ss & 1 & 2 & 3 & 4 & 5 \\
\hline Kar. Psk. Dan. Değer & 26.97 & 4.87 & $\mathbf{1}$ & - & - & - & - \\
Kar. Psk. Dan. Damgalanma & 12.69 & 5.11 & $-.41^{* *}$ & $\mathbf{1}$ & - & - & - \\
Yakın Çevre Damgalanması & 39.43 & 14.56 & $-.09^{*}$ & $.34^{* *}$ & $\mathbf{1}$ & - & - \\
Kendini Damgalama & 21.63 & 6.74 & $-.34^{* *}$ & $.47^{* *}$ & $.31^{* *}$ & $\mathbf{1}$ & - \\
Sosyal Damgalanma & 9.92 & 3.05 & -.09 & $.34^{* *}$ & $.35^{* *}$ & $.42^{* *}$ & $\mathbf{1}$ \\
${ }^{* * *} p<.001{ }^{*} p<.05$ & & & & & & &
\end{tabular}

Tablo 2'de görüldüğü üzere kariyer psikolojik danışmanlığına yönelik tutum ölçeğinin iki boyutu olan değer ile damgalanma arasında negatif yönlü ve anlamlı $(r=-.405 ; p<, 001)$ bir ilişki bulunmaktadır. Diğer taraftan değer alt boyutuyla yakın çevre damgalanması arasında $(r=-.094 ; p<.05)$ ve kendini damgalama $(r=-.335 ; p<.001)$ arasında negatif yönlü anlamlı ilişkiler bulunmuştur. Buna karşın değer alt boyutu ile sosyal damgalanma arasında anlamlı bir ilişki bulunmamaktadır $(r=-.087 ; p>.05)$. Kariyer psikolojik danışmanlığına yönelik tutumun damgalanma alt boyutu ile ise yakın çevre damgalaması $(r=.341 ; p<.001)$, kendini damgalama $(r=.468, p<.001)$ ve sosyal damgalama $(r=.343 ; p<.001)$ arasında pozitif yönde anlamlı ilişkiler bulunmuştur. Son olarak yakın çevre damgalaması ile kendini damgalama $(r$ $=.313 ; p<.001)$ ve sosyal damgalama $(r=.348 ; p<.001)$ arasında da pozitif ilişkiler mevcutken benzer şekilde kendini damgalama ve sosyal damgalama arasında da pozitif yönlü ilişki olduğu $(r=.415 ; p<.001)$ sonucuna ulaşılmıştır. Değişkenler arasındaki korelasyon değerleri incelendiğinde bağımsız değişkenler arasında orta ve düşük düzeyli ilişki bulunduğu görülmektedir. Dolayısıyla yordayıcı değişkenler arasında çoklu bağlantı probleminin olmadığ1 söylenebilir.

Değişkenler arasındaki ilişkileri temel alan ve alanyazına dayalı olarak oluşturulan modelin (Şekil 1) istatistiksel olarak ne düzeyde uyumlu olduğunu belirlemek amaciyla yol analizi yapılmıştır. Yapılan yol analizi kapsamında elde edilen diyagram Şekil 2'de verilmektedir. 


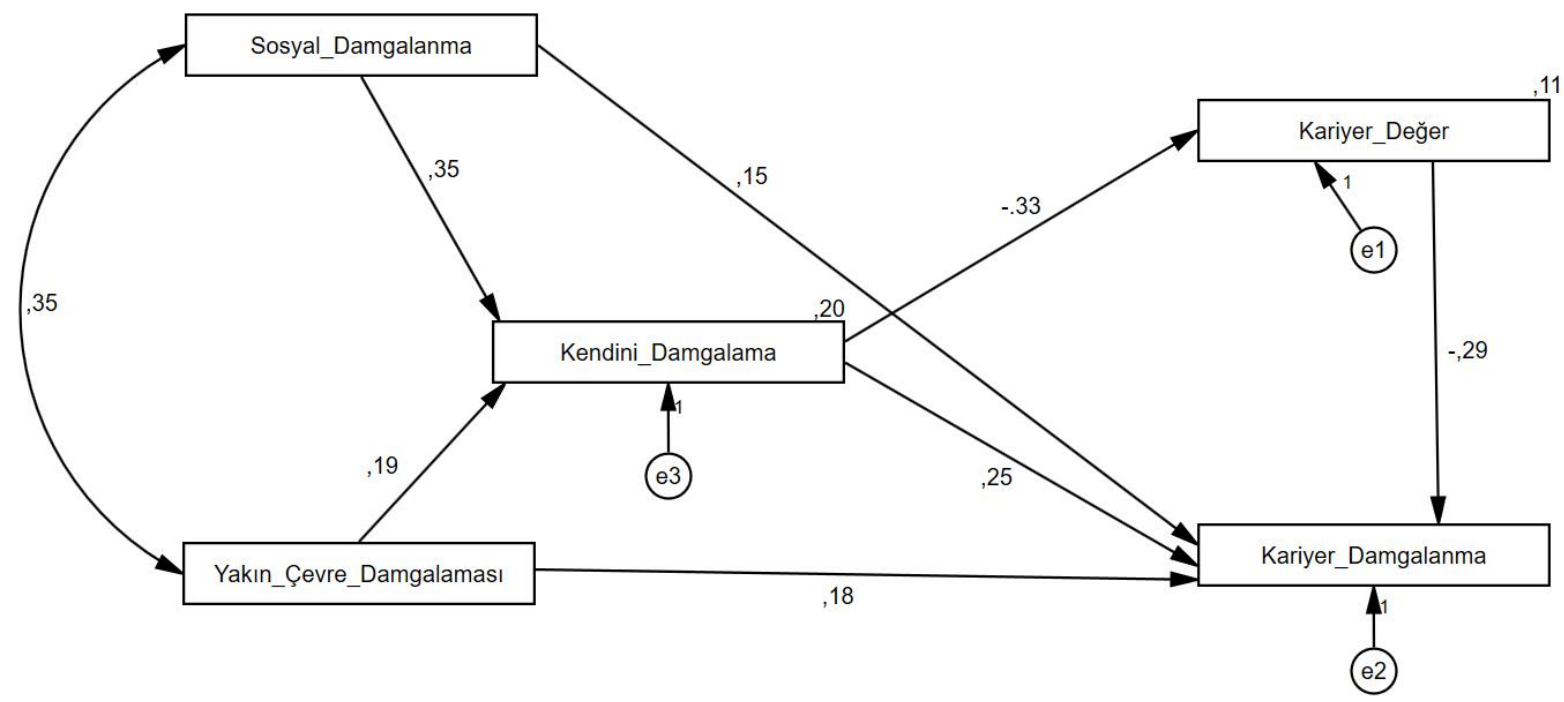

Şekil 2. Yol Analizi Diyagramı

Önerilen modeli test etmek ve modeldeki değişkenlerin birbirleri arasında ne düzeyde bir yordama gücü olduğunu belirlemek amaciyla verilere yol analizi (path analysis) uygulanmıştır. Önerilen modelin test edilmesi amacı ile ilk olarak modelin çalışma verilerine uygun olup olmadığını görmek için çeşitli uygunluk ölçütleri hesaplanmıştır. Buna göre, önerilen modelin $\mathrm{x}^{2}$ değeri 1.849 , .001'den büyük olduğu için anlamlı olduğunu ve kikare/serbestlik derecesi ( $x^{2} / \mathrm{sd}$ ) oranı (.924) 3'ten küçük olduğu için modelin mükemmel uyuma işaret ettiği görülmektedir. Diğer taraftan GFI (0.99), AGFI (0.98), CFI (1.00) ve NFI (0.99) değerlerinin alanyazında belirtildiği üzere (Tabachnik ve Fidell, 2020) .95 üzerinde olduğu ve yaklaşık hataların ortalama karekökü (RMSEA) değerinin .00 olarak bulunduğu için verilerin modele mükemmel düzeyde uyum sağladığı söylenebilir.

\section{Tartışma}

Mevcut araştırmanın ilk amacını üniversite öğrencilerinin kariyer psikolojik danışmanlığına karşı tutumlarının cinsiyete göre farklılaşıp farklılaşmadığını incelemek oluşturmaktadır. Araştırmanın ikinci amacı ise kişilerin kariyer psikolojik danışmanlığına ilişkin tutumlarında yakın çevre damgalanması, sosyal çevre damgalanması ve kişinin kendini damgalamasının nasıl bir rol oynadığını incelemektir. Bu kapsamda ilk olarak üniversite öğrencilerinin kariyer psikolojik danışmanlığına yönelik tutumlarının cinsiyete göre farklılaşıp farklılaşmadığı ara değişkenli bir model kapsamında test edilmiştir. Buna göre kariyer psikolojik danışmanlığına yönelik tutumun damgalanma alt boyutunda erkeklerin ortalama puanlarının kadınlarınkinden anlamlı düzeyde yüksek olduğu görülmüştür. Diğer bir ifadeyle erkekler kariyer psikolojik danışmasından yararlanmaları halinde kadınlara göre daha fazla damgalanma yaşayacaklarını düşünmektedirler. Bu sonuç alanyazındaki birçok çalışmanın bulguları ile benzerlikler göstermektedir. Konu ile ilgili araştırmalar kariyer psikolojik danışmanlığı yardımı alma konusunda erkeklerin kadınlara göre daha fazla damgalanma korkusu yaşadığını göstermektedir (Al-Darmaki, 2012; Di Fabio ve Bernaud, 2008; Ludwikowski vd., 2009). Bu sonuç daha çok toplumsal cinsiyet algılarıyla açıklanabilir. Örneğin Günindi-Ersöz (2010) çoğu toplumun erkeklere atfettiği bağımsızlık, duyguların 
gizlenmesi, başat olma, yetenekli olma, kararlarını kolayca verebilme ve kendine güveni olma gibi eril özelliklerin olduğunu belirtmektedir. Dolayısıyla bir erkeğin, yaşadığı kariyer probleminden dolayı kariyer psikolojik danışma yardımı alması durumu toplumun kendisinden beklediği özellikleri karşılamadığı ve yetersiz olduğunu düşünmesine yol açabilir. Benzer şekilde kişi alacağı yardımla birlikte toplum tarafından yetersiz olarak da damgalanacağını düşünebilir. Diğer taraftan kadınlara yüklenen, duyguları ifade edebilme ve daha bağımlı ya da yardıma muhtaç olma gibi geleneksel toplumsal cinsiyet rolleri ise kadınların yardım arama davranışının toplum tarafından daha kabul edilebilir olduğunu göstermektedir. Sonuç olarak kariyer psikolojik danışmasına yönelik damgalanma konusunda kültürel anlamda kadın ve erkeklere yüklenen çeşitli geleneksel toplumsal cinsiyet özelliklerinin etkili olabileceği söylenebilir.

Araştırmanın ikinci amacı doğrultusunda ise kariyer psikolojik danışmanlığına yönelik tutumun değer ve damgalanma alt boyutlarının sosyal damgalanma ve yakın çevre damgalanması tarafından ne düzeyde açıklandığı ve bu ilişkide kendini damgalamanın aracı rolü yol analizi ile incelenmiştir. Alanyazın incelendiğinde hem psikolojik danışmada (Vogel vd., 2007) hem de kariyer psikolojik danışmasında (Ludwikowski vd., 2009) kendini damgalamanın çevresel damgalama ile profesyonel yardım aramaya yönelik tutumlar arasındaki ilişkiye tam olarak aracılık ettiği sonucuna ulaşan araştırmalara rastlanmaktadır. Mevcut çalışmada da benzer sonuçlar elde edilmiştir. Bu sonuçlar, toplum ve yakın çevre tarafından gerçekleşen damgalama eğiliminin kendini damgalama olarak içselleştirilebileceğini ve daha sonra kendini damgalamanın yardım arama konusundaki tutumları şekillendirmede doğrudan bir rol oynayabileceğini göstermektedir.

Yukarıdaki bulgulara ek olarak mevcut araştırmada toplumun ve yakın çevrenin kariyer psikolojik danışma yardımı alanlara karşı damgalama durumunun kişinin kariyer psikolojik danışmaya karşı tutumunu da doğrudan yordadığı sonucuna ulaşılmıştır. Fakat yakın çevre ve toplum tarafından damgalanma durumu, kendini damgalamanın aracilık etkisi olmadığında kariyer psikolojik danışmanlığına yönelik tutumu daha az yordamaktadır. Bu sonuç Türkiye'nin nispeten daha çok toplulukçu bir yapıya sahip olmasıyla açıklanabilir. Toplulukçu gruplarda toplumun ihtiyaçları, eğilimleri ve tercihleri kişinin davranışlarını düzenleyici ve yönlendirici bir etkiye sahiptir (Markus ve Kitayama, 1991; akt. Wasti ve EserErdil, 2007). Dolayısıyla kişinin içinde bulunduğu topluma uyum sağlama eğiliminden dolayı toplumun kariyer psikolojik danışmanlığına karşı damgalayıcı tutumu kişinin kariyer danışmanlığına karşı tutumunda bir farklılık oluşturabilir.

\section{Sınırlılıklar ve Öneriler}

Mevcut araştırma kendi içinde bazı önemli sınırlılıkları barındırmaktadır. İlk sınırlılığın katılımcıların cinsiyetlerindeki dağılımdan kaynaklandığg söylenebilir. Araştırmaya katılan gönüllü katılımcıların büyük çoğunluğu kadınlardan oluşmaktadır. Bu durum cinsiyetler arasında çıan farklılıkların genellenmesini zora sokmaktadır. Dolayısıyla gelecekte yapılacak araştırmalar için katılımcıların cinsiyetlerinin daha dengeli bir şekilde dağılmasına özen gösterilmesi önerilebilir. Araştırmanın diğer bir sınırlılığı ise ilişkisel desen temelinde yürütülmüş olmasıdır. İlişkisel araştırmalarda değişkenlerin birbirlerini ne derece yordadıklarına ilişkin sonuçların elde edilmesine karşın bu değişkenler arasında neden sonuç bağlantılarının kurulması mümkün değildir. Dolayısıyla gelecek araştırmalarda deneysel 
desenlerin kullanılarak değişkenler arasındaki ilişkilerin daha net ortaya çıkarılması mümkün olabilir.

Araştırmadan elde edilen sonuçlara dayanılarak kariyer psikolojik danışmanlığı alanında çalışan uzmanlara çeşitli öneriler verilebilir. Mevcut araştırmada çevresel damgalamaların kişinin kariyer psikolojik danışmanlığına yönelik tutumu yordadığ fakat kendini damgalama aracı değişken olarak modele girdiğinde bu yordama gücünün arttı̆̆1 görülmüştür. Kariyer psikolojik danısmanlığı kapsamındaki hizmetler göz önüne alındığında toplum tarafından yapılan damgalamaya müdahale etmenin nispeten daha zor olduğu fakat kendini damgalamaya karşı müdahale geliştirmenin daha kolay olduğu söylenebilir (Ludwikowski vd., 2009). Dolayısıyla kişilerin kendilerini damgalama eğilimlerini azaltacak ve kontrol altına alacak müdahale programlarının geliştirilmesi büyük önem arz etmektedir. Diğer taraftan mevcut araştırmada kişilerin kariyer psikolojik danışmanlığına yönelik tutumlarının cinsiyete göre değişip değişmediği incelenmiş ve ayrı bir analizde ise damgalanma çeşitlerinin kariyer psikolojik danışmanlığına yönelik tutumu ne düzeyde yordadığı araştırılmıştır. Gelecekteki çalışmalarda mevcut araştırmada geliştirilen modelin de cinsiyete göre farklılaşıp farklılaşmadığ

\section{Bilgilendirme}

Mevcut araştırma birinci yazar Aida Köse'nin “Kariyer Psikolojik Danışmanlığına Yönelik Tutumda Kendini Damgalamanın Aracı Rolü" isimli yüksek lisans tez çalışması kapsamında gerçekleştirilmiştir.

\section{Kaynakça}

Acun-Kapıkıran, N. \& Kapıkıran, Ş. (2013). Psikolojik yardım aramada kendini damgalama ölçeği: Geçerlik ve güvenirlik. Türk Psikolojik Danışma ve Rehberlik Dergisi, 5(40), 131-141. https://dergipark.org.tr/en/pub/tpdrd/issue/21460/230035 adresinden alınmıştır.

Al-Darmaki, F. R. (2012). Relationships between career counseling attitudes and self-esteem and self-efficacy among emirati university students. Journal of Career Development, 39(2), 143-161. DOI: $10.1177 / 0894845310380046$

Büyükgöze-Kavas, A. (2017). Kariyer psikolojik danışmanlığına yönelik tutum ölçeğinin Türkçe formu: Geçerlilik ve güvenirlik çalışması. Türk Psikolojik Danışma ve Rehberlik Dergisi, 7(48), 8396. https://dergipark.org.tr/en/pub/tpdrd/issue/41239/498107 adresinden alınmıştır.

Di Fabio, A. \& Bernaud, J. L. (2007). The help-seeking in career counseling. Journal of Vocational Behaviour, 72, 60-66. DOI: 10.1016/j.jvb.2007.10.006

Çivan, K. (2019). Psikolojik danışman adaylarının psikolojik yardım almaya ilişkin tutumları. (Yüksek lisans tezi, Hacettepe Üniversitesi, Ankara). Erişim adresi: https://tez.yok.gov.tr/

Çokluk, Ö., Şekercioğlu, G., \& Büyüköztürk, Ş. (2014). Sosyal bilimler için çok değiş̧kenli istatistik SPSS ve LISREL uygulamaları. Ankara: Pegem Akademi.

Fouad, N. A., Guillen, A., Harris-Hodge, E., Henry, C., Novakovic, A., Terry, S., \& Kantamneni, N. (2006). Need, awareness, and use of career services for college students. Journal of Career Assessment, 14(4), 407-420. DOI: 10.1177/1069072706288928 
Günindi-Ersöz, A. (2010). Türk atasözleri ve deyimlerinde kadına yönelik toplumsal cinsiyet rolleri. Gazi Türkiyat Türkoloji Araştırmaları Dergisi, 1(6), 167-182. https://atif.sobiad.com/index.jsp?modul=makale-goruntule\&id=AWCurCOYoDuH9Br d-Zu adresinden alınmıştır.

Gürsoy, O., \& Gizir, C. A. (2018). Üniversite öğrencilerinin psikolojik yardım almaya yönelik tutumları: Sosyal damgalanma, kendini damgalama, öznel sıkıntıları açma, benlik saygısı ve cinsiyetin rolü. Türk Psikolojik Danışma ve Rehberlik Dergisi,8(49), 137-155. https://dergipark.org.tr/en/pub/tpdrd/issue/40627/487349 adresinden alınmıştır.

Işık, E. (2007). Üniversite öğrencilerinin üniversitelerinde verilen kariyer danışmanlı̆̆ı hizmetlerine ilişkin algı ve beklentileri. XVI. Eğitim Bilimleri Kongre Kitabı (2. Cilt). Ankara: Detay Yayıncılık.

Kalkan, M. ve Odacı, H. (2005). Cinsiyet ve cinsiyet rolünün psikolojik yardım almaya ilişkin tutumlarla ilişkisi. Türk Psikolojik Danışma ve Rehberlik Dergisi, 3(23), 57-64. https://avesis.ktu.edu.tr/yayin/7e2ce7b6-bb1a-4a6f-bd9d-924c7886141f/cinsiyet-ve-cinsiyetrolunun-psikolojik-yardim-almaya-iliskin-tutumlarla-iliskisi adresinden alınmıştır.

Kızıldağ, S., Demirtaş-Zorbaz, S., Gençtanırım, D., \& Arıcı, F. (2012). Hacettepe Üniversitesi öğrencilerinin psikolojik danışma yardımı almaya ve bu yardımın sunulduğu birimlere ilişkin görüşleri.Mersin Üniversitesi Eğitim Fakültesi Dergisi, 8(3), 185-196. https://dergipark.org.tr/en/pub/mersinefd/issue/17381/181578?publisher=mersin adresinden alınmıştır.

Kim, P. Y., Britt, T. W., Klocko, R. P., Riviere, L. A., \& Adler, A. B. (2011). Stigma, negative attitudes about treatment, and utilization of mental health care among soldiers. Military Psychology, 23(1), 65-81. DOI: 10.1080/08995605.2011.534415

Komiya, N., Good, G. E. ve Sherrod, N. B. (2000). Emotional openness as a predictor of college students' attitudes toward seeking psychological help. Journal of Counseling Psychology, 47, 138143. DOI: $10.1037 / 0022-0167.47 .1 .138$

Korkut-Owen, F. (2018). Üniversite öğrencilerinin kariyer gelişim ihtiyaçları. Yaşadıkça Eğitim Dergisi, 32(2), 28-39. https://acikerisim.iku.edu.tr/handle/11413/5455 adresinden alınmıştır.

Lau, P. L., Anctil, T., Ee, G. T., Jaafar, J. L. S., \& Kin, T. G. (2020). Self-concept, attitudes toward career counseling, and work readiness of malaysian vocational students. The Career Development Quarterly, 68(1), 18-31. DOI: 10.1002/cdq.12210

Leaf, P. J., Bruce, M. L., \& Tischler, G. L. (1986). The differential effect of attitudes on the use of mental health services. Social Psychiatry, 21(4), 187-192. Retrieved from https://link.springer.com/article/10.1007/BF00583999

Ludwikowski, W., Vogel, D., \& Armstrong, P. I. (2009). Attitudes toward career counseling: The role of public and self-stigma. Journal of Counseling Psychology, 56(3), 408. DOI: 10.1037/a0016180

Major, B., \& O'brien, L. T. (2005). The social psychology of stigma. Annual Review Psychology, 56, 393-421. DOI: $10.1146 / 56.091103 .070137$

Multon, K. D., Heppner, M. J., Gysbers, N. C., Zook, C., \& Ellis-Kalton, C. A. (2001). Client psychological distress: An important factor in career counseling. The Career Development Quarterly, 49(4), 324-335. DOI: 10.1002/j.2161-0045.2001.tb00960.x

Rochlen, A. B., Mohr, J. J., \& Hargrove, B. K. (1999). Development of the Attitudes Toward Career Counseling Scale. Journal of Counseling Psychology, 46(2), 196-206. DOI: 10.1037/00220167.46.2.196 
Serim, F. \& Cihangir-Çetinkaya, Z. (2015). Yetişkinlerin psikolojik yardım arama tutumlarının yordanması. Ege Eğitim Dergisi, 16(1), 177-198. DOI: 10.12984/eed.79026

Sezer, S., \& Gülleroğlu, D. (2016). Psikolojik yardım arama tutumlarını yordayan değişkenler: Kendini damgalama, özsaygı, psikolojik yardım almış olma. Uludağ Üniversitesi Ĕğitim Fakültesi Dergisi, 29(1), 75-93. DOI: 10.19171/uuefd.52149

Sezer, S., \& Kezer, F. (2013). Psikolojik yardım aramada yakın çevre damgalaması ölçeği'nin bir Türk örnekleminde geçerlik ve güvenirliği. Ankara Üniversitesi Eğitim Bilimleri Fakültesi Dergisi, 46(1), 181-201. DOI: 10.5350/DAJPN2013260204

Tabachnik, B. G. ve Fidell, L. S. (2020). Çok değgişkenli istatistiklerin kullanımı. Ankara: Nobel.

Topkaya, N. (2011a). Psikolojik yardım alma niyetinin sosyal damgalanma, tedavi korkusu, beklenen yarar, beklenen risk ve tutum faktörleriyle modellenmesi. (Doktora tezi, Ege Üniversitesi, İzmir). Ege Üniversitesi, İzmir). Erişim adresi: https://tez.yok.gov.tr/

Vogel, D. L., Wade, N. G., \& Ascheman, P. (2008). Measuring the public stigma associated with seeking psychological help. Unpublished manuscript.

Vogel, D. L., Wade, N. G. ve Ascheman, P. L. (2009). Measuring perceptions of stigmatization by others for seeking psychological help: reliability and validity of a new stigma scale with college students. Journal of Counseling Psychology, 56 (2), 301-308. DOI: 10.1037/a0014903

Vogel, D. L., Wade, N. G., \& Haake, S. (2006). Measuring the self-stigma associated with seeking psychological help. Journal of Counseling Psychology, 53, 325-337. DOI: 10.1037/00220167.53.3.325

Vogel, D. L., Wade, N. G., \& Hackler, A. H. (2007). Perceived public stigma and the willingness to seek counseling: The mediating roles of self-stigma and attitudes toward counseling. Journal of Counseling Psychology, 54(1), 40-50. DOI: 10.1037/0022-0167.54.1.40

Vogel, D. L., Wade, N. G., Wester, S. R., Larson, L., \& Hackler, A. H. (2007). Seeking help from a mental health professional: The influence of one's social network. Journal of Clinical Psychology, 63(3), 233-245. DOI: 10.1002/jclp.20345

Wasti, S. A. ve Eser-Erdil, S. (2007). Bireycilik ve toplulukçuluk değerlerinin ölçülmesi: Benlik kurgusu ve INDCOL ölçeklerinin Türkçeye geçerlemesi. 15. Ulusal Yönetim ve Organizasyon Kongresi, May1s, Sakarya.

Whiston, S. C., \& Rahardja, D. (2008). Vocational counseling process and outcome. Handbook of Counseling Psychology, 4, 444-461.

Zeren, Ş. G., Erus, S. M., \& Amanvermez, Y. (2017). University students' attitudes towards seeking psychological help and their responses related to the offer of help. International Online Journal of Educational Sciences, 9(2), 1-15. DOI: 10.15345/iojes.2017.02.011 